\title{
A new find of calc-alkaline lamprophyres in Thanewasna area, Western Bastar Craton, India
}

\author{
R R Meshram ${ }^{1}, \mathrm{M}$ L Dora ${ }^{2}$,*, R NAik ${ }^{3}, \mathrm{M}_{\text {ShareeF }}^{4}, \mathrm{G}$ Gopalakrishna ${ }^{4}$, \\ T Meshram ${ }^{2}$, S R BASWANi ${ }^{2}$ and $\mathrm{K}$ R RANDive ${ }^{5}$ \\ ${ }^{1}$ Geological Survey of India, NER, Guwahati, India. \\ ${ }^{2}$ Geological Survey of India, Petrology Division, CR, Nagpur, India. \\ ${ }^{3}$ Geological Survey of India, NER, Shillong, India. \\ ${ }^{4}$ EPMA Laboratory, NCEGR, GSI, Bengaluru, India. \\ ${ }^{5}$ P. G. Department of Geology, RTM Nagpur University, Nagpur, India. \\ ${ }^{*}$ Corresponding author.e-mail: dorageol@gmail.com
}

MS received 15 January 2018; revised 28 March 2018; accepted 31 March 2018; published online 17 November 2018

Lamprophyre dykes within the granitoid and charnockite are reported for the first time from the Western Bastar Craton, Chandrapur district, Maharashtra. It shows porphyritic-panidiomorphic texture under a microscope, characterised by the predominance of biotite phenocrysts with less abundance of amphibole and clinopyroxene microphenocryst. The groundmass is composed more of K-feldspars over plagioclase, amphiboles, clinopyroxene, biotite, chlorite, apatite, sphene and magnetite. The mineral chemistry of biotite and magnesio-hornblende is indicative of minette variety of calc-alkaline lamprophyre (CAL), which is further supported by preliminary major oxides and trace element geochemistry. This unique association of CAL with granitoid provides an opportunity to study the spatio-temporal evolution of the lamprophyric magma in relation to the geodynamic perspective of the Bastar Craton.

Keywords. Lamprophyre; minette; Thanewasna; central India.

The lamprophyric magmas are typically formed at low degrees of partial melting of an upper mantle source at a depth of 100-150 km (Rock 1991). These magmas are known to have very high concentrations of volatiles $\left(\mathrm{F}, \mathrm{CO}_{2}, \mathrm{H}_{2} \mathrm{O}\right)$ and incompatible trace elements (light REE, $\mathrm{Zr}, \mathrm{Sr}, \mathrm{Ba}$ ). Such high volatile contents are thought to have been formed either from a previously volatile and incompatible element-rich mantle sources (Ulrych et al. 1993) or from $\mathrm{CO}_{2}-\mathrm{H}_{2} \mathrm{O}-\mathrm{F}$-bearing fluid-rich metasomatism (McKenzie 1989). Lamprophyres are not simply textural varieties of common plutonic or volcanic rocks, but they are more complex in nature (Seifert 2005). They have been regarded as hybrid rocks, resulting from interactions of mantle melts with more evolved crustal material by processes of magma mixing (mafic-felsic melts) and/or assimilation of country material (Rock 1991).

In India, lamprophyres occur in the rocks of various ages, tectonic settings and cratonic areas (Fareeduddin and Mitchell 2012). In the Bastar Craton lamprophyres, lamproite and kimberlite are known to occur in the eastern parts (Mainkar et al. 2004; Lehmann et al. 2010; Chalapathi Rao et al. 2016); however, lamprophyres have not been so far reported from the Western Bastar Craton (WBC). In this communication, a new occurrence 


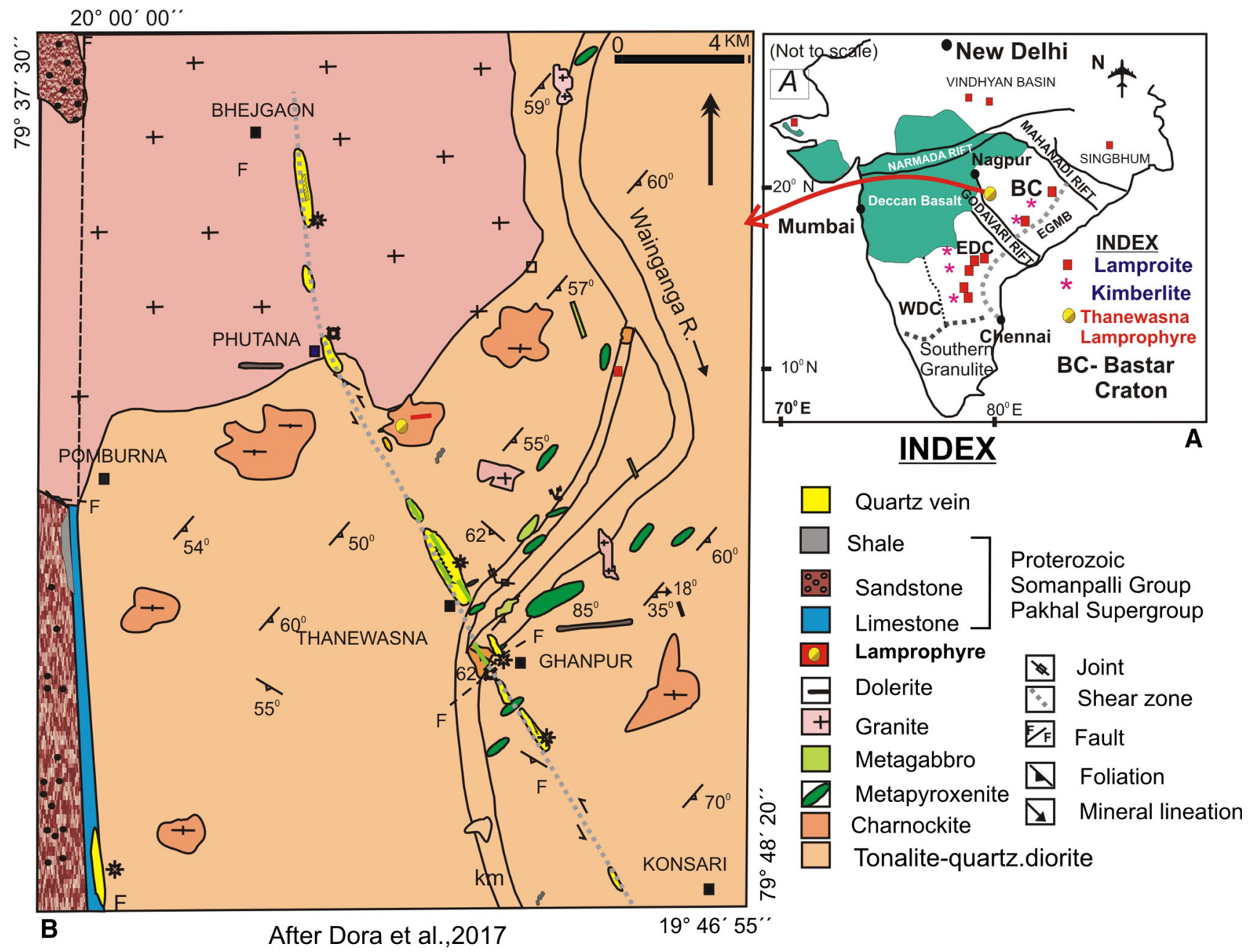

Figure 1. (A) Generalised geological map of India showing the location of the Thanewasna lamprophyre (study area (box)) in the western margin of the Bastar Craton, central India. The occurrence of other lamproites and kimberlites in various cratons is also shown after Chalapathi Rao et al. (2016) and (B) geological map of the Thanewasna lamprophyre in the WBC (Dora et al. 2017).

of calc-alkaline lamprophyre (CAL) dykes from the Thanewasna area of the WBC is being reported for the first time.

The Thanewasna area is located in the northern fringe of Gondpipri Mafic-Ultramafic Complex (GMUC), along with the WBC (figure 1A). Gneisses, granitoid, granulites, supracrustals (older and younger) and mafic igneous suites constitute the bulk of the geology of the Bastar Craton (Ramachandra 2004; Srivastava 2006). This Craton has experienced several episodes of mafic magmatism during the Precambrian, which is evident from a variety of Precambrian mafic rocks exposed in all parts of the Bastar Craton in the form of dykes and volcanic rocks. They intrude all the older suites of rocks (basement gneisses, older supracrustals and granitoids) predominantly along the NE-SW direction. The study area comprises tonalitetrondjhemite-granodiorite (TTG), quartz diorite, charnockite, metapyroxenite and metagabbroic rocks, which are intruded by younger undeformed dolerites (figure 1B) (Dora et al. 2017). These rocks form the basement for overlying Meso- to Neo-Proterozoic platform sediments of the Pakhal Supergroup and Gondwana sediments along the N-S to NNW-SSE trending Godavari rift. GMUC consists of several tectonically dismembered websterite-olivine gabbro-gabbro bodies found in a $10 \mathrm{~km}$ long NE-SW trending linear belt within TTG and charnockite-enderbite (figure 1B).

Small dykelets of lamprophyres of about 2-5 m length and $40-50 \mathrm{~cm}$ width (figure $1 \mathrm{~B}$ ) intrude through the granitoid and charnockite. The dykes 

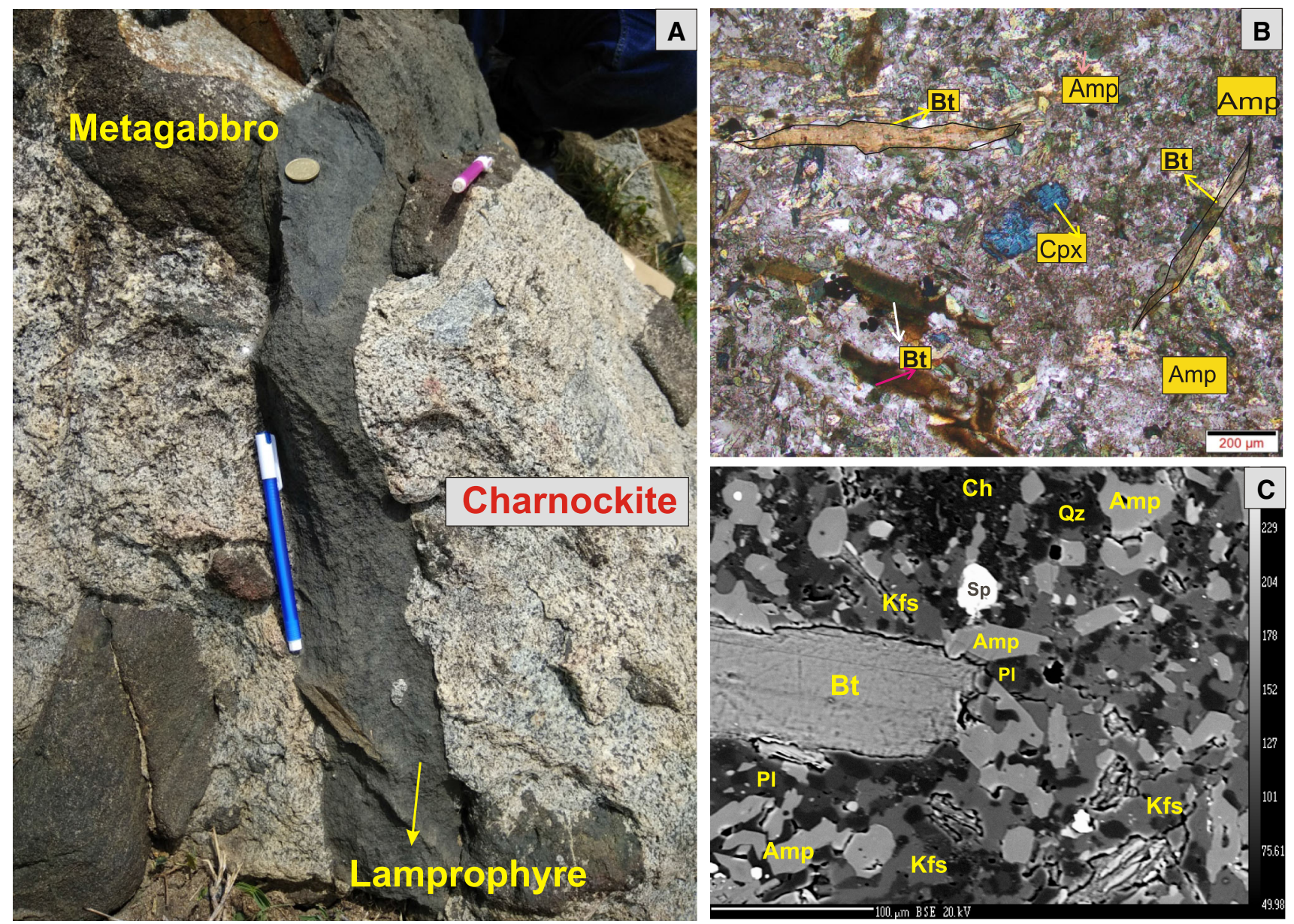

Figure 2. Field, photomicrographs and back scattered electron (BSE) images depicting the overall field and petrographic aspects of the Thanewasna lamprophyre. (A) Lamprophyre intruded into charnockite and meta-gabbro; (B, C) photomicrograph and BSE image showing predomination of biotite phenocrysts in a fine-grained matrix containing scattered grains of amphibole, clinopyroxene, K-feldspar and plagioclase (cross polarised light); Abbreviations. Bt: biotite; Qt: quartz; Cpx: clinopyroxene; Amp: amphibole; Kfs: K-feldspar; Chl: chlorite; Sp: spinel.

show a sharp contact without any prominent chilled margins (figure 2A), which are accentuated due to colour contrast among the lithologies. However, the dyke margins are often arcuate, curvy and show interaction with the host rock. The presence of xenoliths of country rock embedded within lamprophyre dyke and microveins as well as stringers emanating from lamprophyres into the country rock indicates 'synkinematic' interaction between the two. It is, therefore, possible that the host granitoids, charnockite and intrusive lamprophyre may also share a spatio-temporal coherence; possibly indicating their syngenetic association, at least at the time of their emplacement. This also indicates that the lamprophyre dykes are synplutonic, a feature most commonly observed in Precambrian granitoid plutons where mixing and mingling of felsic and mafic magmas is envisaged (Jayananda et al. 1995).
Petrography of the dykes shows porphyriticpanidiomorphic texture common for worldwide lamprophyres (Rock 1991), wherein phenocrysts of clinopyroxene, amphibole and mica occur within the groundmass of potassic as well as plagioclase feldspars, mica, amphiboles, clinopyroxene, opaque oxides, chlorite, glass and mesostasis (figure 2B and $\mathrm{C}$ ). The presence of ocelli is also observed very prominently. Olivine is not observed in these studied dykes. Therefore, on the whole, preponderance of biotite over amphiboles, potassic feldspars over plagioclase feldspars and the presence of diopsidic augite suggests that this lamprophyre is classified as minette (Le Maitre 2002).

Chemical compositions of all mineral phases were quantitatively determined by electron probe microanalyser (EPMA-CAMECA SX-100(WDS)) at GSI, NCEGR laboratory, Bengaluru, India. Point analyses were performed under the operating 
Table 1. Representative mineral chemistry of the Thanewasna lamprophyre, WBC.

\begin{tabular}{|c|c|c|c|c|c|c|c|}
\hline Mineral name & Biotite & Amphibole & Clinopyroxene & Feldspar & Apatite & Magnetite & Chlorite \\
\hline No. of analysis & $n=37$ & $n=25$ & $n=4$ & $n=27$ & $\mathrm{n}=5$ & $n=4$ & $n=5$ \\
\hline $\mathrm{SiO}_{2}$ & 35.85 & 43.87 & 51.78 & 63.00 & 0.18 & 0.4 & 28.38 \\
\hline $\mathrm{TiO}_{2}$ & 3.92 & 1.13 & 0.17 & 0.02 & 0.02 & 0.23 & 0.65 \\
\hline $\mathrm{Al}_{2} \mathrm{O}_{3}$ & 13.92 & 10.06 & 1.92 & 20.37 & 0.00 & 0.39 & 17.1 \\
\hline $\mathrm{Cr}_{2} \mathrm{O}_{3}$ & 0.022 & 0.02 & 0.02 & 0.01 & 0.00 & 0.47 & 0 \\
\hline $\mathrm{FeO}$ & 17.40 & 15.69 & 8.96 & 0.29 & 0.41 & 92.73 & 24.33 \\
\hline $\mathrm{MnO}$ & 0.18 & 0.29 & 0.45 & 0.02 & 0.05 & 0.08 & 0.23 \\
\hline $\mathrm{MgO}$ & 13.78 & 11.63 & 14.14 & 0.01 & 0.01 & 0.17 & 16.68 \\
\hline $\mathrm{CaO}$ & 0.25 & 12.27 & 21.74 & 1.96 & 56.02 & 0.07 & 0.85 \\
\hline $\mathrm{Na}_{2} \mathrm{O}$ & 0.07 & 1.33 & 0.55 & 3.28 & 0.03 & 0 & 0.01 \\
\hline $\mathrm{K}_{2} \mathrm{O}$ & 8.10 & 1.23 & 0.11 & 10.10 & 0.03 & 0 & 0.09 \\
\hline $\mathrm{P}_{2} \mathrm{O}_{5}$ & - & - & - & - & 41.36 & - & - \\
\hline Total & 93.53 & 97.56 & 98.53 & 99.08 & 98.15 & 94.61 & 88.33 \\
\hline $\mathrm{O}$ & 22.000 & 23.000 & 6.000 & 8.000 & & & \\
\hline $\mathrm{Si}$ & 5.513 & 6.585 & 1.940 & 2.897 & & & \\
\hline $\mathrm{Ti}$ & 0.454 & 0.129 & 0.005 & 0.001 & & & \\
\hline $\mathrm{Al}$ & 2.525 & 1.781 & 0.085 & 1.101 & & & \\
\hline $\mathrm{Cr}$ & 0.003 & 0.002 & 0.001 & 0.000 & & & \\
\hline $\mathrm{Fe}$ & 2.242 & 1.970 & 0.281 & 0.011 & & & \\
\hline Mn & 0.024 & 0.037 & 0.014 & 0.001 & & & \\
\hline $\mathrm{Mg}$ & 3.163 & 2.604 & 0.790 & 0.001 & & & \\
\hline $\mathrm{Ca}$ & 0.043 & 1.974 & 0.873 & 0.094 & & & \\
\hline $\mathrm{Na}$ & 0.022 & 0.387 & 0.040 & 0.288 & & & \\
\hline K & 1.586 & 0.237 & 0.006 & 0.599 & & & \\
\hline $\mathrm{XMg}$ & 0.586 & 0.570 & 0.738 & & & & \\
\hline $\mathrm{XFe}$ & 0.414 & 0.430 & 0.262 & & & & \\
\hline Fs & & & 0.14 & & & & \\
\hline En & & & 0.39 & & & & \\
\hline Wo & & & 0.44 & & & & \\
\hline An & & & & 0.09 & & & \\
\hline $\mathrm{Ab}$ & & & & 0.28 & & & \\
\hline Or & & & & 0.61 & & & \\
\hline
\end{tabular}

conditions of accelerating voltage of $15 \mathrm{kV}, 20$ $\mathrm{nA}$ of current intensity, a beam diameter of $1 \mu \mathrm{m}$ and counting time of $20 \mathrm{~s}$. Thallium acid phthalate (TAP), large pentaerythritol (LPET) and large ion lithium fluoride (LLIF) crystals were employed for measurement. A number of natural and synthetic standards were used for calibration. Natural standards were used for all elements except in Mn and Ti. Analyses of the selected and representative mineral phases are given in table 1 . It was observed that the amphiboles show a broad range in composition (table 1) such as magnesio-hornblende and tschermakite. Clinopyroxene is a pure diopside with restricted compositional range $\left(\mathrm{Wo}_{42-46} \mathrm{En}_{38-40} \mathrm{Fs}_{12-15}\right)$, without any prominent optical or compositional zoning observed during the step-scan analysis of the phenocrysts. They also lack significant concentration of titanium (0.10-0.26 apfu) and aluminium (0.99$2.62 \mathrm{apfu})$. In the lamprophyre classification plot, based on $\mathrm{Mg} \#$ vs. $\mathrm{SiO}_{2} / \mathrm{Al}_{2} \mathrm{O}_{3}$, the clinopyroxenes are mostly confined to the CAL field (figure 3A). Feldspars plot in the sanidine field along with only minor anorthite and albite components. Mica exhibits a typical compositional range of biotite and few straddle over the biotite-phlogophite transition. The above mineralogy and their chemistry confirm the calc-alkaline signature and the composition resembles with minette observed worldwide (Rock 1991; Mitchell 1995; Randive 2008) (figure 3B and C).

The Thanewasna lamprophyres exhibit limited geochemical variations for both the major elements as well as the trace elements (table 2). They are sub-alkaline in nature and show a variation in major oxides i.e., in $\mathrm{SiO}_{2}$ (48.31-54.28 wt\%), 

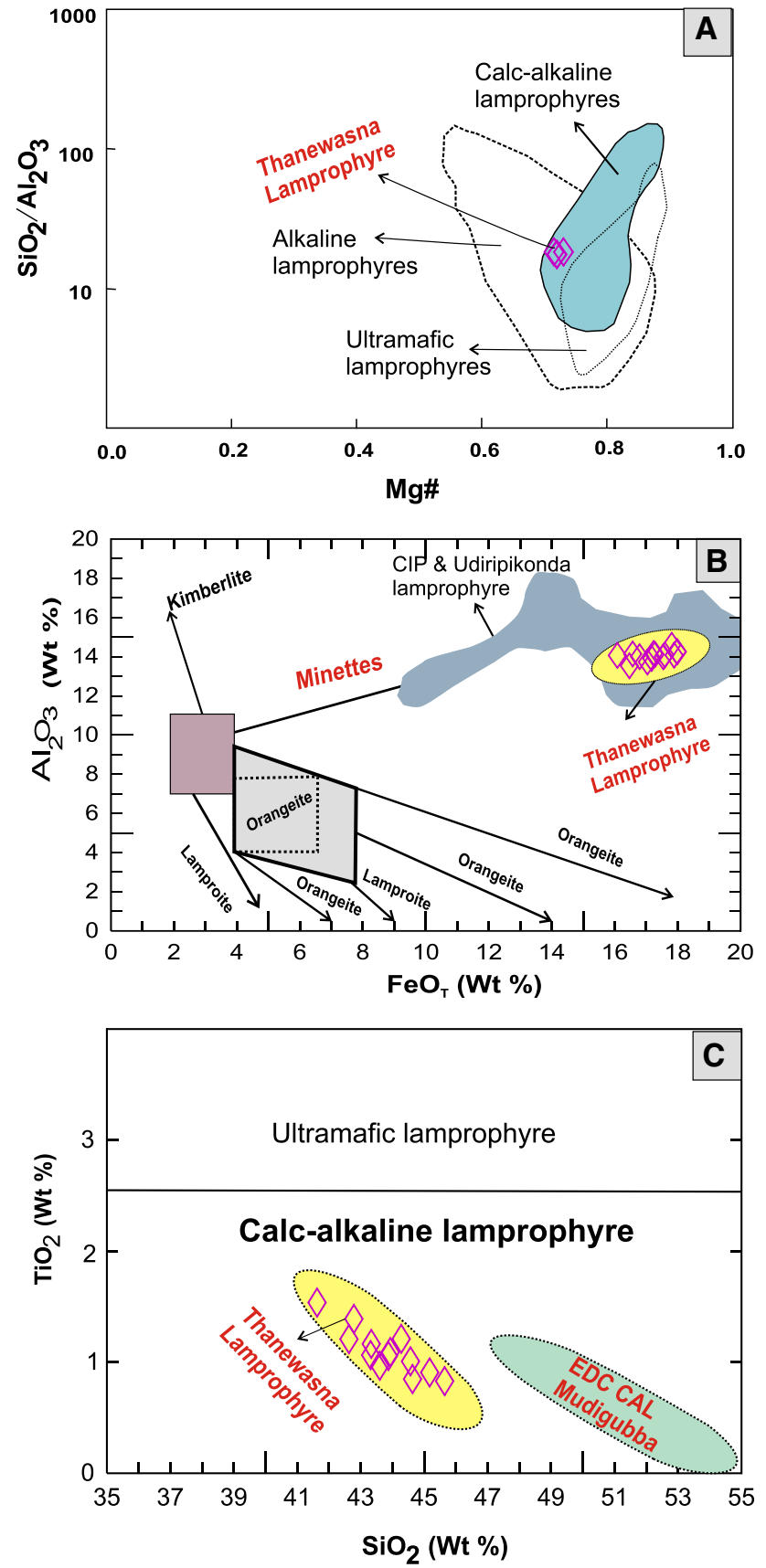

Figure 3. (A) $\mathrm{Mg} \#$ vs. $\mathrm{SiO}_{2} / \mathrm{Al}_{2} \mathrm{O}_{3}$ of the Thanewasna lamprophyre compared with worldwide lamprophyres (fields from Rock 1991; Stoppa et al. 2014). (B) $\mathrm{FeO}_{\mathrm{T}}$ vs. $\mathrm{Al}_{2} \mathrm{O}_{3}$ variation of micas of the Thanewasna lamprophyres showing fractionation trends of minettes type, diagram after Mitchell (1995); (C) $\mathrm{TiO}_{2}$ (wt\%) vs. $\mathrm{SiO}_{2}$ (wt\%) plot (after Rock 1991) for the amphibole suggesting calc-alkaline nature of the Thanewasna lamprophyre. Field taken: Eastern Dharwar Craton CAL-Udiripikonda and Mudigubba (Pandey et al. 2017a; Pandey et al. 2017b).

$\mathrm{Fe}_{2} \mathrm{O}_{3}(9.52-14.93 \mathrm{wt} \%), \mathrm{MgO}(6.06-7.36 \mathrm{wt} \%)$, $\mathrm{CaO}(6.48-10.04 \mathrm{wt} \%), \mathrm{K}_{2} \mathrm{O}(0.67-4.3 \mathrm{wt} \%), \mathrm{TiO}_{2}$ (1.04-1.11 wt\%) and almost constant $\mathrm{Al}_{2} \mathrm{O}_{3}$ (12.57-12.59 wt\%) contents. Similarly, they show a
Table 2. Representative major oxide and trace element data of the Thanewasna lamprophyre, WBC.

\begin{tabular}{|c|c|c|c|}
\hline Sample no. & GP/21JU/1 & GP/21JU/2 & $\mathrm{GP} / 21 \mathrm{JU} / 3$ \\
\hline $\mathrm{SiO}_{2}$ & 48.31 & 54.03 & 54.28 \\
\hline $\mathrm{Al}_{2} \mathrm{O}_{3}$ & 12.58 & 12.59 & 12.57 \\
\hline $\mathrm{Fe}_{2} \mathrm{O}_{3}$ & 14.93 & 9.71 & 9.52 \\
\hline $\mathrm{CaO}$ & 10.04 & 6.48 & 6.79 \\
\hline $\mathrm{MgO}$ & 7.36 & 6.18 & 6.06 \\
\hline $\mathrm{Na}_{2} \mathrm{O}$ & 1.8 & 1.86 & 1.88 \\
\hline $\mathrm{K}_{2} \mathrm{O}$ & 0.67 & 4.3 & 3.87 \\
\hline $\mathrm{TiO}_{2}$ & 1.05 & 1.11 & 1.04 \\
\hline $\mathrm{P}_{2} \mathrm{O}_{5}$ & 0.15 & 0.95 & 0.93 \\
\hline $\mathrm{MnO}$ & 0.19 & 0.13 & 0.13 \\
\hline LOI & 1.05 & 1.37 & 1.5 \\
\hline Total & 98.13 & 98.71 & 98.57 \\
\hline $\mathrm{Ba}$ & 149 & 1747 & 1684 \\
\hline $\mathrm{Sr}$ & 127 & 431 & 436 \\
\hline $\mathrm{V}$ & 286 & 173 & 172 \\
\hline $\mathrm{Zr}$ & 84 & 380 & 376 \\
\hline $\mathrm{Rb}$ & 37 & 268 & 215 \\
\hline $\mathrm{Cu}$ & 135 & 75 & 70 \\
\hline $\mathrm{Pb}$ & 10 & 35 & 35 \\
\hline $\mathrm{Zn}$ & 205 & 90 & 95 \\
\hline $\mathrm{Co}$ & 145 & 60 & 55 \\
\hline $\mathrm{Ni}$ & 50 & 30 & 30 \\
\hline $\mathrm{Cr}$ & 255 & 140 & 135 \\
\hline $\mathrm{Ag}$ & 1 & 1 & 1 \\
\hline $\mathrm{Y}^{*}$ & 15.01 & 17.95 & 16.88 \\
\hline $\mathrm{Nb}^{*}$ & 4.95 & 13.07 & 13.36 \\
\hline
\end{tabular}

higher content of $\mathrm{Ba}$ (149-1747 ppm), Sr (127-436 ppm), V (172-286 ppm) and Zr (84-380 ppm). The Thanewasna lamprophyre plot in the calc-alkaline field in $\mathrm{TiO}_{2}$ vs. $\mathrm{Al}_{2} \mathrm{O}_{3}$ diagram (figure $4 \mathrm{~A}$ ) and similar nature also represented in binary trace element $\mathrm{Nb} / \mathrm{Pb}$ vs. $\mathrm{V} / \mathrm{Cr}$ diagram (figure $4 \mathrm{~B}$ ). These lamprophyres also correlated with other CALs of India and the world (Pandey et al. 2017a). The Thanewasna lamprophyre shows low $\mathrm{Ti}$ content than most of the reported CALs (figure 4A), but matching with Mudigubba CAL (Pandey et al. 2017b and references therein).

The relationship between CALs and granitoid plutonism has persisted from about 2.7 Ga to the present (Rock 1991). Earlier view about this association regards that the lamprophyre is one form of residuum from granitoid magma, whereas the subsequent views considered lamprophyres to have intruded fractures induced by the earlier emplacement of unrelated granitoids (Carmichael et al. 1974), and therefore non-related by origin. However, subsequent workers have shown that CAL-granitoid association is both temporally as 

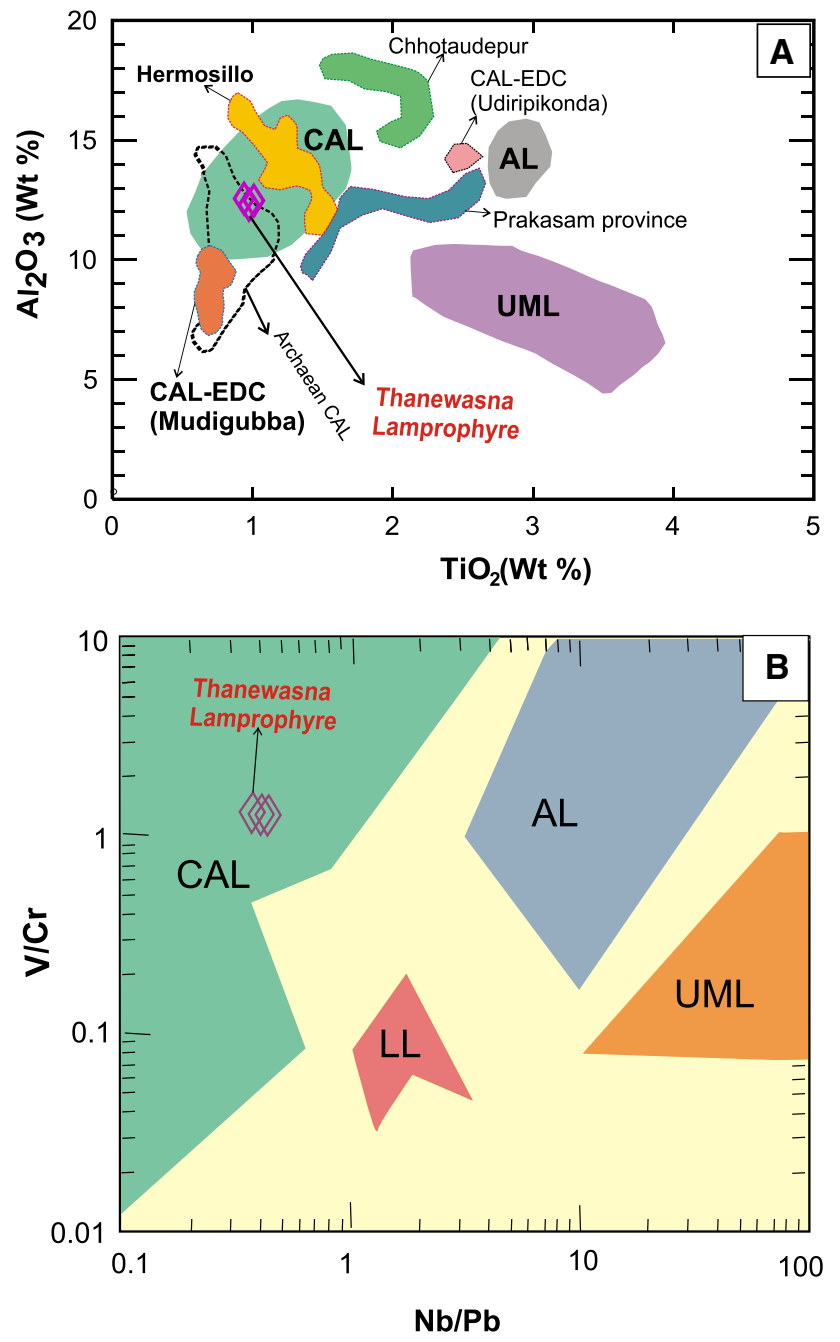

Figure 4. (A) $\mathrm{Al}_{2} \mathrm{O}_{3}$ (wt\%) vs. $\mathrm{TiO}_{2}$ (wt\%) classification plots for the Thanewasna lamprophyres. Fields for CAL (calc-alkaline lamprophyres), AL (alkaline lamprophyres), UML (ultramafic lamprophyres) and Archaean CAL from different cratons are taken from Lefebvre et al. (2005) and references there in. The field taken: Prakasam Province lamprophyres at eastern margin of the Cuddapah basin (Madhavan et al. 1998; Kumar and Rathna 2008; Meshram et al. 2015); Chhotaudepur lamprophyres, NW India (Chalapathi Rao et al. 2012), Eastern Dharwar Craton CAL-Udiripikonda and Mudigubba (Pandey et al. 2017a; Pandey et al. 2017b) and Hermosillo lamprophyres, Mexico (Garza et al. 2013). (B) Simple discrimination between the lamprophyre branches using trace element ratios of $\mathrm{Nb} / \mathrm{Pb}$ vs. $\mathrm{V} / \mathrm{Cr}$.

well as spatially closed and therefore need not be either a part of residuum or subsequent, often unrelated, magmatic episode. The Thanewasna area provides this unique opportunity to study one such CAL-granitoid relationship and its bearing on the evolution of an ancient cratonic lithosphere. The Thanewasna area is also known for hosting the second-biggest copper deposit in central India after Malanjkhand (Dora et al. 2017). The geodynamic evolution of $\mathrm{WBC}$ in relation to economically significant mineralisation belt, therefore, assumes the prominence. In this view, the new find of CALs will be crucial in addressing geology and tectonic history of the WBC.

\section{Acknowledgements}

We thank Shri. S N Meshram, Additional Director General and HOD, Geological Survey of India (GSI) and Shri. B K Bhandaru, Deputy Director General, RMH-IV, Central Region, GSI, Nagpur, for their kind encouragement and permission to publish this short paper in rapid communication. We extend our sincere thanks to Prof. N V C Rao, the Chief Editor of Journal of Earth System Science for his encouragement. We also thank reviewer Shri. R Vijay Kumar, Director, GSI, for his valuable suggestions that helped to improve the short paper.

\section{References}

Carmichael I S E, Turner F J and Verhoogen J 1974 Igneous petrology; McGraw-Hill, New York.

Chalapathi Rao N V, Dharma Rao C V and Das S 2012 Petrogenesis of lamprophyres from Chhota Udepur area, Narmada rift zone, and its relation to Deccan magmatism; J. Asian Earth Sci. 45 24-39.

Chalapathi Rao N V, Atiullah Burgess R, Nanda P, Choudhary A K, Sahoo S, Lehmann B and Chahong N 2016 Petrology, ${ }^{40} \mathrm{Ar} /{ }^{39} \mathrm{Ar}$ age, $\mathrm{Sr}-\mathrm{Nd}$ isotope systematics, and geodynamic significance of an ultrapotassic (lamproitic) dyke with affinities to kamafugite from the easternmost margin of the Bastar Craton; Mineral. Petrol. 110269 293, https://doi.org/10.1007/s00710-015-0403-5.

Dora M L, Randive K R, Ramachandra H M and Suresh G 2017 Iron oxide-copper-gold mineralization at Thanewasna, Western Bastar Craton; Curr. Sci. 112(5) 10.

Fareeduddin and Mitchell R M 2012 Diamonds and their source rocks in India; Geol. Soc. of Ind., Bangalore, 434p.

Garza A O, Dostal J, Keppie J D and Paz-Moreno F A 2013 Mid-Tertiary (25-21 Ma) lamprophyres in NW Mexico derived from subduction-modified subcontinental lithospheric mantle in an extensional backarc environment following steepening of the Benioff zone; Tectonophys. 590 59-71.

Jayananda M, Martin H, Peucat J J and Mahabaleswar B 1995 Late Archaean crust-mantle interactions: Geochemistry of LREE-enriched mantle derived magmas. Example of the Closepet batholith, Southern India; Contrib. Mineral. Petrol. V 119 314-329.

Kumar K V and Rathna K 2008 Geochemistry of the mafic dykes in the Prakasam Alkaline Province of Eastern Ghats Belt, India: Implications for the genesis of continental riftzone magmatism; Lithos 104 306-326. 
Le Maitre R W 2002 Igneous rocks: A classification and glossary of terms, 2nd edn, Cambridge University Press, Cambridge, 236p.

Lefebvre N, Kopylova M and Kivi K 2005 Archaean calcalkaline lamprophyres of Wawa, Ontario, Canada: Unconventional diamondiferous volcaniclastic rocks; Precamb. Res. 138 57-87.

Lehmann B, Burgess R, Frei D, Belyatsky B, Mainkar D, Chalapathi Rao N V and Heaman L M 2010 Diamondiferous kimberlites in central India synchronous with Deccan flood basalts; Earth Planet. Sci. Lett. 290 142-149.

Madhavan V, David K, Mallikharjuna Rao J, Chalapathi Rao N V and Srinivas M 1998 Comparative study of lamprophyres from the Cuddapah Intrusive Province (CIP) of Andhra Pradesh, India; J. Geol. Soc. India 52 621-642.

Mainkar D, Lehmann B and Haggerty S E 2004 The crater-facies kimberlite system of Tokapal, Bastar district, Chhattisgarh, India; Lithos 76 201-217.

McKenzie D 1989 Some remarks on the movement of small melt fractions in the mantle; Earth Planet. Sci. Lett. 95 53-72.

Meshram T M, Shukla D and Behera K K 2015 Alkaline lamprophyre (camptonite) from Bayyaram area, NE margin of the Eastern Dharwar Craton, southern India; Curr. Sci. 109(10-11) 1931-1934.

Mitchell R H 1995 Kimberlites, orangeites and related rocks; Plenum Press, New York, 410p.

Pandey A, Chalapathi Rao N V, Pandit D, Pankaj P, Pandey R, Sahoo S and Kumar A 2017a Subduction - Tectonics in the evolution of the eastern Dharwar craton, southern India: Insights from the post-collisional calc-alkaline lamprophyres at the western margin of the Cuddapah basin; Precamb. Res. 298 235-251.

Corresponding editor: N V CHALAPATHI RAO
Pandey A, Chalapathi Rao N V, Chakrabarti R, Pandit D, Pankaj P, Kumar A and Sahoo S 2017b Petrogenesis of a Mesoproterozoic shoshonitic lamprophyre dyke from the Wajrakarur kimberlite field, eastern Dharwar craton, southern India: Geochemical and $\mathrm{Sr}-\mathrm{Nd}$ isotopic evidence for a modified sub-continental lithospheric mantle source; Lithos 292-293 218-233, https://doi.org/10. 1016/j.lithos.2017.09.001.

Ramachandra H M 2004 A review of terrane evolution in the Precambrian Dharwar and Bastar Craton; GSI Spec. Publ. 84 1-21.

Randive K R 2008 Compositional variation of micas from the lamprophyre dykes of Bakhatgarh-Phulmal Area, Jhabua District, M.P., India; In: Indian dykes: Geochemistry, geophysics and geochronology (eds) Rajesh K. Srivastava R K, Sivaji Ch and Chalapathi Rao N V, Narosa Publishing House Pvt. Ltd., New Delhi, India.

Rock N M S 1991 Lamprophyres; Blackie, Glassgow, 285p.

Seifert W 2005 REE-Zr and Th rich titanite and associated accessory minerals from a Kersentite in Frankenwald, Germany; Miner. Petrol. V 84.3 129-146.

Srivastava, Rajesh K 2006 Geochemistry and petrogenesis of neoarchaean high-mg low-ti mafic igneous rocks in an intracratonic setting, central India Craton: Evidence for boninite magmatism; Geochem. J. 40 15-31.

Stoppa F, Rukhlov A S, Bell K, Schiazza M and Vichi G 2014 Lamprophyres of Italy: Early cretaceous alkaline lamprophyres of Southern Tuscany, Italy; Lithos $\mathbf{1 8 8}$ 97-112.

Ulrych J, Pivec E, Zak K, Bendl J and Bosak P 1993 Alkaline and ultramafic carbonate lamrophyres in Central Bohemian Carboniferous basins, Czech Republic; Miner. Petrol. V 48 65-81. 